\title{
The Dynamics of Rebuilding Trust and Trustworthiness in Marital Relationship Post Infidelity Disclosure
}

\author{
Anselmus Agung Pramudito ${ }^{* 1}$,Wenty Marina Minza ${ }^{2}$ \\ ${ }^{1,2}$ Faculty of Psychology, Universitas Gadjah Mada ${ }^{1}$ Department of Psychology, \\ Faculty of Humanities and Education Sciences, Universitas Katolik Musi Charitas
}

Submitted 31 October 2020 Accepted 26 June 2021 Published 30 August 2021

\begin{abstract}
Infidelity has been one of the leading causes of marital divorce for couples in many countries, including Indonesia. For couples surviving infidelity in marriage, some aspects of the marital relationship such as trust and trustworthiness can be affected. Rebuilding trust and trustworthiness after the disclosure of infidelity can be one of the most important factors in recovering the quality of marital relationship. This research adopted qualitative research method with phenomenological approach to explore the dynamics of rebuilding trust and trustworthiness in marital relationship post infidelity disclosure. The study found that the victim of infidelity rebuilt their trust toward the perpetrator in five aspects. Three of these were personal aspects, including risk identification and prevention, predictability, and belief; and two were relational aspects, including intimacy and reciprocity. Whereas the perpetrators of infidelity rebuilt their trustworthiness by showing four aspects: commitment, openness and honesty, benevolence, and religiosity. Those aspects provided implications in recovery of marital relationship post infidelity disclosure.
\end{abstract}

Keywords: infidelity disclosure; marital relationship; trust; trustworthiness

Trust is a psychological condition that contains the intention to accept risk based on positive expectations of intentions or behaviors of other parties (Buskens, 2002; Rousseau et al., 1998). From psychological point of view, trust is seen as a level at which individuals believe that their partner will support for achieving the specific goals of both parties (Simpson, 2007). Trust is a social capital that lays psychological foundation for happy social relationships (Füzér, 2016; Rempel et al., 1985; Simpson, 2007), including marital relationship. However, trust will not be given if the trustor is in a situation of absence or lack of trust (Buskens, 2002). One of the greatest causes of a lack of trust in a marital relationship is the existence of an infidelity case (Amato \& Previti, 2003). In an infidelity case, there has been a great betrayal of trust by one of the parties of the couple, so that the perpetrator of the infidelity will be much more difficult to be trusted again by the spouse (Baucom et al., 2009; Peluso, 2007). That condition is because any relationship between individuals which is based on trust will be broken by betrayal (Wardhati \& Faturochman, 2006).

As an impact of the betrayal of trust, infidelity could cause destruction in marital harmony and could be the greatest cause for a couple to divorce (Amato \& Previti, 2003; Baucom et al., 2009; Kuroki, 2013; Shackelford et al., 2007; Zare, 2011). Olson et al. (2002) found that infidelity increased the probability to divorce twice higher than other marital problems. Following through that research, Allen and Atkins (2012) found that married couples with infidelity problem are four times more likely to divorce than those who did not have infidelity problem.

The cases of infidelity seem to have reached a level of concern so that it is important to be investigated further. This level of concern can be seen from the prevalence rate of infidelity recorded in the United States, which ranges from 20\% to 40\% (Allen \& Atkins, 2012; Marin et al., 2014). This fact shows that infidelity has touched nearly half of all marriages in the United States, and can be a serious

${ }^{*}$ Address for correspondence: anselmodito@gmail.com 
threat to the survival of the couple who experience it (van Hooff, 2017). In Indonesia, cases of infidelity also occupy one of the top positions as the main cause of divorce. The national online media reported that most divorce cases at the Religious Courts in several regions in Indonesia, such as Greater Jakarta, Surabaya, Makassar and Yogyakarta, were triggered the cases of infidelity (Pitakasari, 2012; Prasetyo, 2017; Purnama, 2017; Takariawan, 2015).

In addition to divorce as the worst impact according to Amato and Previti (2003), on personal level, in the early period post infidelity disclosure, spouse that became the victim of infidelity could feel great emotional turmoil, including expressing anger, experiencing feelings of self-blame, resistance to the perpetrator of the infidelity, and trying to suppress volatile feelings (Baucom et al., 2009; Olson et al., 2002). Victim of infidelity also could experience helplessness, lower confidence, feeling of being left behind, confusion, and tendency to make justification to leave their spouse (Abrahamson et al., 2012; Fisher et al., 2008; Lishner et al., 2008; Snyder et al., 2008). Specifically, impacts of infidelity disclosure could also be different between men and women. In research done by Miller and Maner (2008), men tend to show anger and have greater tendency to be violent, while women tend to show deep sadness and have a greater tendency to seek for social support, especially from close relatives. Personal impacts of infidelity disclosure could also be felt by perpetrator of infidelity, of which include depression, deep guilt, suicidal thoughts, and acute anxiety, especially when the infidelity disclosure caused separation or threat of divorce (Fisher et al., 2008; Snyder et al., 2008). On relational level, couple who experienced infidelity showed marital instability, and higher distrust compared to couple who did not experienced infidelity (Marin et al., 2014). To commit in a good relationship after committing a betrayal is difficult, of which Wardhati and Faturochman (2006) found that often marital relationship cannot be restored and continued unless the fault is corrected.

The threat of infidelity recurrence in the future could also exist because the tendency of infidelity recurrence would increase if the individual had an experience of infidelity before (Young et al., 1995). In such uncertain situation, the couple, especially the victim of infidelity, was faced with the choice of keeping the marriage, or ending it. The decision should not be made emotionally. Both choices, either keeping the marriage or divorce, had consequences and needed strong commitment to go through with it (Baucom et al., 2009). Baucom et al. (2009) also stated that the turmoil arise in the heart and mind of victim could cause the victim to have a difficulty to decide between the two choices. In the decision-making process, victim needed support from a third party, either counsellor or close relatives, to help reduce negative emotions and help change the responses to be more positive.

By deciding to save the marriage, the couple needed to recover their marital relationship. In early period of recovery, victim of infidelity had to go through forgiving process toward the perpetrator. However, even if the victim was able to forgive the perpetrator, and had decided to keep the marriage, it did not mean that the relationship had been fully recovered (Baucom et al., 2009). After victim went through the process of forgiving, a further effort was needed to rebuild victim's trust toward perpetrator. Trust rebuilding after the disclosure of infidelity would be very difficult to realize if the couple could not work together on conflict resolution positively (Baucom et al., 2009). On the other hand, the perpetrator had to rebuild trustworthiness in themselves by showing faithfulness and behavioral integrity overtime (Baucom et al., 2009). Faithfulness and behavioral integrity shown by the perpetrator could increase predictability and support rebuilding victim's trust toward perpetrator (Goldie, 2013). Therefore, each party needed to work together in efforts to resolve conflict positively in order to rebuild victim's trust toward perpetrator, and to rebuild trustworthiness in perpetrator so that the marital relationship could be fully recovered (Baucom et al., 2009; Dickie, 2015).

A such, trust and trustworthiness are two important things to recover marital relationship post infidelity disclosure. According to Baucom et al. (2009), the main problem for couples who decided to survive in marital relationship post infidelity disclosure was the rebuilding of trust and trustworthiness. Trust in early relationship is built by four main aspects: risk taking, interdependence, predictability, and belief of trustor toward trustee (Evans et al., 2013; Evans \& Krueger, 2009; Hardin, 2002; Luhmann, 2000; Mayer et al., 1995; Rempel et al., 1985; Rousseau et al., 1998), whereas trustworthiness in early relationship is built by three main aspects: ability, benevolence and integrity (Mayer et al., 1995). However, those aspects might be different in the dynamics of rebuilding trust and trustworthiness post infidelity disclosure. To view the dynamics, this research will especially focus on the married couples who have a history of infidelity in their marital relationship but have decided to 
stay together and against a divorce. This research emphasizes on the dynamics of marital relationship, in the rebuilding of trust from the side of the victim, and the rebuilding of trustworthiness from the side of the perpetrator until the couple can achieve total recovery in their marital relationship post infidelity disclosure.

\section{Method}

\section{Research participants}

Participants of this research were three married couples (six people) with infidelity history that was clearly acknowledged, but never divorced. The infidelity was also confirmed to be truly over. One couple of participants were recruited through the researcher's relation, and two couples of participants were recruited through a counsellor who was acquainted with the researcher. Each participant expressed his/her willingness consciously and voluntarily to participate in this research together with his/her spouse and to provide in-depth information on their experience. This willingness was stated in a written informed consent that had been understood, approved, and signed by each participant.

The first two couples had a history of infidelity in their marriage with husband as perpetrator and wife as victim. Here on, we refer to couple 1 (Mr. A and Mrs. B) and couple 2 (Mr. C and Mrs. D). One other couple had a history of infidelity in marriage with wife as perpetrator and husband as victim, of which we refer to couple 3 (Mr. E and Mrs. F). Couple 1 and 2 had the same educational background and job. Husbands of couple 1 and 2 both had elementary education and worked as drivers, while the wives of both couples had high-school education and were housewives. Husbands from both couples were younger than the wives. The case was different on couple 3, of which the husband had a higher education and was older in age compared to the wife. The husband worked as an employee, and the wife was a housewife.

\section{The History of Infidelity Disclosure of Couple 1}

Couple 1 (Mr. A and Mrs. B) married in 2000 and had two children. In 2003, Mr. A was involved in infidelity with a friend who was also acquainted with Mrs. B. The infidelity happened for about one year and included emotional and sexual relationship. During that time, Mrs. B knew about the infidelity, but she only kept it to herself. As time went by, Mrs. B knew that the infidelity had ended by itself. In 2006, Mr. A was involved in infidelity for the second time. The second infidelity was done for about eight months with a woman he knew from a dating agency program. However, this infidelity was unknown by Mrs. B. Mr. A did not confess that the relationship was an infidelity because it did not last long, and just included emotional, not sexual relationship. In 2009, Mr. A was once again involved in emotional and sexual infidelity. This infidelity was done with Mrs. B's little sister and was disclosed in 2011 when Mrs. B's little sister was known to be pregnant. Mrs. B's little sister then confessed that her pregnancy was because of her relationship with Mr. A. At that time, a great conflict emerged that had an impact in Mrs. B's strong desire to divorce. However, Mr. A refused to divorce from Mrs. B, and threatened to kill himself if Mrs. B really left him. Mr. A also stated that he chose Mrs. B instead of her sister. Mrs. B mulled over her decision and decided to stay in their marriage.

\section{The History of Infidelity Disclosure of Couple 2}

Couple 2 (Mr. C and Mrs. D) married in 2001 and had three children. In the tenth year of marriage, Mr. C was involved in infidelity with a best friend of Mrs. D. This infidelity happened for five years in 2011 until 2016 and included emotional and sexual relationship. The disclosure of this infidelity started when Mr. C was involved in corruption in his company. Mr. C then negotiated with the company so that the case was not reported to the police and promised to return the money that he had stolen. Then, this corruption case was known by Mrs. D because Mr. C then was fired unceremoniously and received a bill of fifty million rupiah from the company. Mr. C then confessed that the corrupt money was used to fulfill the needs of his infidelity partner. At that moment, Mrs. D wanted to leave Mr. C as soon as possible. She also wanted to kill herself, but could be stopped by Mr. C. This couple then went to a counsellor and received moral support to recover their marital relationship. 


\section{The History of Infidelity Disclosure of Couple 3}

Couple 3 (Mr. E and Mrs. F) married in 2010 and had one child. In the sixth year of marriage, on August 2016, Mrs. F was involved in infidelity by having emotional and sexual relationship with a man who was her ex-colleague. When the infidelity happened, Mrs. F was working as a Sales Promotion Girl (SPG). This infidelity was disclosed and ended in February 2017. When the infidelity was disclosed, Mr. E asked Mrs. F's infidelity partner to apologize. Mrs. F's infidelity partner then met with both of them and apologized. Mr. E forgave and considered the problem finished. But then, on August 2017 , infidelity was done again by Mrs. F with a different man. The man was eight years younger than Mrs. F and was introduced to her by her SPG colleague. This infidelity was disclosed and ended on February 2018 in a much severe outcome for Mrs. F because it ended in an unwanted pregnancy. As a note, Mr. E and Mrs. F did not have a sexual activity at all for a long time until that moment. When finding out the second infidelity and the unwanted pregnancy, Mr. E physically and verbally abused Mrs. F. Mr. E was also thinking about divorcing Mrs. F. During those times, Mr. E tried to meet up with Mrs. F's second infidelity partner, but repeatedly failed. This couple then visited a counsellor and received a moral support to recover their marital relationship.

\section{Data Collection and analysis}

This research employed a qualitative research method with phenomenological approach. The use of a phenomenological approach was generally intended to generate awareness and meaning (Smith, 2009). Therefore, this study focused on the meaning of each participant in rebuilding of trust and trustworthiness in their marital relationship after infidelity disclosure. Data was collected through in-depth interview, participant observation and member checking. Researcher developed an interview guideline based on literature review of relevant topic. Researcher then employed the guideline through probing and prompting techniques during the interviews. Interviews were recorded and written in transcript. As a triangulation step, researcher wrote field notes of observation in couples' activities. Researcher also took another triangulation step through member checking. Member checking was done to each participant by verifying the truth and completeness of the research results obtained from the entire interview with each participant. The analysis process began by writing interview transcripts and reading them repeatedly. The important parts of transcript relevant to research topic were selected. The selected data were given the initial codes. Then, those initial codes were conceptualized and categorized into emergent themes and superordinate themes.

\section{Results}

\section{Early Process of Relationship Recovery Post Infidelity Disclosure}

In the early days after infidelity was disclosed, all couples had different processes to cope with infidelity and to recover in early stages. In the couple 1 case, Mrs. B stated that she wished to divorce from Mr. A but she had to reconsider her decision due to strong rejection from her husband including a threat of suicide. On the other hand, Mr. A realized his fault that he had committed infidelity and led to confess his infidelity completely, apologize to Mrs. B, and to ask Mrs. B not to remember the infidelity problem anymore. Mr. A also stated that he did not want to divorce from Mrs. B, and promised that he would be faithful again. Basically, the efforts done by couple 1 in the early days of the infidelity disclosure was different from couple 2 and 3 because couple 1 did not seek a counselor to help them to cope with the infidelity problem. Mr. A and Mrs. B seemed to cope and settled the problem between themselves. Efforts done by Mr. A made Mrs. B acknowledged that her husband sincerely wished to correct his faults and to keep the unity of their family. This could be seen from Mr. A's decision to end communication with Mrs. B's little sister. Mrs. B slowly began to orgive and accept Mr. A again although still felt hur every time she remembered the infidelity history. However, Mrs. B also had self-awareness as a wife that encouraged herself to accept Mr. A again. From Mrs. B 's confession, if she could forgive and accept Mr. A again, she would feel peace in her heart.

The process of relationship recovery of couple 2 began with Mr. C 's apology to Mrs. D for the infidelity he had done. Mr. C also tried to keep his marriage by refusing to separate and divorce from 
Mrs. D. In the early days after the infidelity was disclosed, Mr. C felt grateful to be able to really get away from the infidelity, but he had found that it was hard to be trusted again by Mrs. D. This could be seen from the frequent times Mrs. D showed suspicion about Mr. C, especially if Mr. C communicated with the opposite sex. Mrs. D also often expressed her hurt feeling if Mr. C brought up the infidelity he had done before. At that time, Mrs. D seemed sensitive to Mr. C's every behavior. Mr. C also felt that he was often blamed by Mrs. D when he was doing something, even small things. Mrs. D admitted that he started to forgive Mr. C in the span of a month or so. However, Mrs. D had not really been able to forgive Mr. C's infidelity partner until approximately six months after the infidelity disclosure. Various efforts had been made by $\mathrm{Mr}$. $\mathrm{C}$ to recover their marital relationship, starting from taking more responsibilities to his family and being more active in helping with household tasks, as well as trying to fulfill everything wished by Mrs. D. As stated above, different from couple 1, Mr. C and Mrs. D tried to seek a professional help. With the help and support from a counselor, Mrs. D then slowly began to be able to forgive and accept Mr. C again. Mrs. D also did not have a desire to revenge the infidelity and made an agreement with Mr. C to no longer bring up the history of the infidelity. Moreover, Mrs. $\mathrm{D}$ gave a moral support to Mr. C to rise from distress due to the infidelity. This seemed different from the victims in couple 1 and 3 because Mrs. D as victim in couple 2 even gave support on the healing process of the perpetrator's psychological condition. Thus, Mrs. D personally could help in keeping the unity of their marital relationship.

In couple 3, Mr. E, as the victim of infidelity, admitted that sometimes he still remembered the infidelity history done by Mrs. F. Same with two other victims in couple 1 and 2, this became an obstacle to forgive and trust Mrs. F again in the beginning of the infidelity disclosure. However, Mr. E tried hard not to remember the infidelity history anymore, and tried to forgive Mrs. F slowly from time to time. Mrs. F herself was still worried about the possibility of infidelity as revenge that might be done by Mr. E in the future. Different from the current condition of the victims in couple 1 and 2, Mr. E still felt difficult to fully trust Mrs. F, and thought that their marital relationship would never be the same. That was because the infidelity happened twice in a short time interval. Similar with couple 2, this couple also tried to seek a counselor to help them. With the help and support from a counselor, Mr. E continually made efforts to recover their marital relationship. One of the ways that Mr. E had taken is to do self-introspection of his own faults when in the past he was involved in infidelity by hiring prostitute, even though at first he did not think it was an infidelity. As an impact of his self-introspection, Mr. E also tried to reduce his tendency to blame Mrs. F. Mr. E also prayed diligently for their marital relationship recovery and surrendered to God so he would never bring up the history of infidelity anymore. Mr. E believes in God's guidance and intervention that infidelity will never happen anymore in the future. Mr. E's belief in God then helped his personal recovery. Mr. E also believed that Mrs. F has been recovered physically, psychologically and spiritually. During his recovery period, Mr. E tried to trust Mrs. F again because he thought that distrust to his wife would distract his mind and daily activities. Overall, different from couple 1 and 2 that had achieved fully recovery process of their marital relationship, the recovery process of couple 3 was still in early stages because the time interval from last infidelity disclosure to this research period was short, which was about five months.

\section{The Aspects of Trust Rebuilding}

Findings showed five aspects to rebuild trust post infidelity disclosure. Three aspects were personally showed by the victims: risk identification and prevention, predictability, and belief. Two other aspects were relationally built by the couples: intimacy and reciprocity. Each aspect is described in turn.

\section{Risk Identification and Prevention}

Trust post infidelity disclosure firstly was rebuilt by the victims by doing efforts to identify and prevent the risk of infidelity recurrence in the future. The efforts was done by monitoring perpetrator's work activities via phone and often checking perpetrator's mobile phone routinely (victim in couple 1), identifying the perpetrator's daily activities at work through his co-workers, and asking perpetrator to break his relationships with all friends from his past (victim in couple 2), prohibiting the perpetrator from returning to work (victim in couple 3), identifying the perpetrator's social relationship, reminding 


\section{Pramudito \& Minza || The Dynamics of Rebuilding Trust}

the perpetrator not to establish close relationship with people from opposite sex anymore, and restricting the perpetrator's mobile phones usage (both victims in couple 2 and 3).

"Well, after dropping off his passenger, entering the airport, he called me again. Well, he's like that every day. So, I can monitor him. So, now he is never suspicious. That's every day." (Mrs. B)

"For example, at work, I know who his friends are, who the people are. At least that's all. Then, the boss in the place he works for, I know. They are all fine too. From the boss, from whom, his mother, from whom, I also joined in there, I also know. I know all about people from that store." (Mrs. D)

"I have to keep her in check for twenty-four hours. In a meaning, this monitoring is currently limited to our community, and to be limited to her usage of mobile phone." (Mr. E)

"So, I actually prefer if she doesn't work like that, for now she doesn't work." (Mr. E)

\section{Predictability}

After identifying and preventing the risk of infidelity recurrence, each victim showed predictability in different ways. The victim in couple 1 still saw the possibility of the perpetrator having an infidelity again in the future due to the history of three infidelity disclosures, and his relationship with his ex-girlfriend which almost led to infidelity. The victim in couple 2 did not find any signs of suspicious behavior of the perpetrator, so that the victim predicted that there was no possibility for the perpetrator to have another infidelity. The victim in couple 3 still had anxiety that the perpetrator's infidelity would happen again in the future especially if the perpetrator returned to work.

"Since then, it's started again, so it's not one hundred percent because it's really recurring from the past, right, if it's been twice, three times, it means maybe tomorrow if someone else seduces you again, maybe you can. It depends on his faith, but if I look at it, he actually loves me very much, but there might be a possibility for him to do that." (Mrs. B)

"I also read his handphone, I also reply. His mobile phone is free, nothing is hidden. I see. So, no friendship with women, really not, not even his sister." (Mrs. D)

"In fact, yesterday I imagined those fears. Well, how if she works again? Then how if it happens again? Yesterday I thought about a lot of fear like that." (Mr. E)

Belief

Despite seeing the possibility of recurring the infidelity, the victim in couple 1 still had a belief that the perpetrator will not have another infidelity, if she can pay attention to and take care of the perpetrator, while the victims in couple 2 and 3 had fully belief that the perpetrators would always be faithful in the future.

"About his possibility of having another infidelity, I don't think so, as long as I take care of him, and I can pay attention to him." (Mrs. B)

"I have no such imagination, to recur. I know exactly. He would not repeat such a thing again." (Mrs. D)

"The first, the second, ended up have affair again, but for now I'm sure there can't be the third." (Mr. E)

\section{Intimacy}

All couples made efforts in rebuilding trust relationally through building intimacy that was showed by having more intensive communication and closer relationship, as well as expressing more love. Intensive communication was built by all couples through frequent communication even when they were not together. Closeness of relationship was built through frequent travelling and doing daily activities together. Love was more expressed by perpetrators toward victims between daily activities.

"We often talk to each other. In our leisure, when we don't have any work, we talk to each other, talk about everything. Well, that makes us always strong." (Mrs. B)

"In fact, he loves me more than that, more than yesterday, more than ever, now he loves me so much, more and more. He loves more than ever." (Mrs. D)

"So, the key was communication every day, keep the trust every day. That's all for me, return it again." (Mr. E) 


\section{Pramudito \& Minza || The Dynamics of Rebuilding Trust}

\section{Reciprocity}

The presence of intimacy then encouraged the emergence of reciprocity in the form of mutual understanding that there was no tendency from spouse to act suspiciously which led to infidelity possibility. The couples considered that now their marriages were based on mutual understanding and respect. This aspect was found in couple 1 and 2.

"Yes, we learn to be open, we learn to understand each other. So, for example, if your wife thinks like A, even though I want her to go to B, or I want my wife to want to go east, I want to go west, I personally now have to be able to follow my wife, oh yes, to the east first Who knows, after going east, my wife will invite me to the west with my wish, like that. Now it's more like that. So, understand more, respect each other's decisions." (Mr. A)

"If we don't trust each other, there will be suspicion. If there is suspicion, we must continue to accuse each other, there is no sense of trust. If we trust each other, it means we are strong." (Mrs. B)

"What is certain is that we... loved each other earlier and wanted to be responsible for everything in family matters. We help each other, love each other, help each other's children, want to know each other. Well, that's it. You can build something better." (Mrs. D)

Overall, efforts that were done to rebuild trust personally and relationally on couple 1 and 2 had supported the rebuilding trust in the victims toward the perpetrators and vice versa, the perpetrators could also trust that victims would be faithful by not doing infidelity too as revenge.

\section{The Aspects of Trustworthiness Rebuilding}

Data from perpetrators found four aspects to rebuild trustworthiness post infidelity disclosure: commitment, openness and honesty, benevolence, and religiosity, which are explained below.

\section{Commitment}

Commitment was built by the perpetrators in all couples by making promises to themselves and to the victims that they will never be involved in infidelity anymore. That commitment was also proven by restricting their relationship with opposite "sex fulfilling" the victim's demand to break relationships with all friends in the past, although there was conflicting feeling (perpetrators in couple 2), and obeying victim's demand to not go back working in the same job as before the infidelity disclosure (perpetrator in couple 3).

"I have promised in my heart, and I think about how not to betray my family again. Then I have to tell my wife that I will not repeat the infidelity again." (Mr. A)

"Why do I always say, my wife already believes in me? Because I promised I wouldn't do it again and I don't want to fall again like that, and until now I'm still trying. I'm not just thinking about it, oh my wife already believes in me, then I want to do it again, no, but I still hold on to the trust my wife gave me. Only I will not repeat and will not fall like before again." (Mr. C)

"I have made a commitment that I won't repeat mistakes like that again" (Mrs. F)

\section{Openness and Honesty}

All perpetrators made efforts to show openness and honesty to the victims in their daily lives, especially in their relationship with the opposite sex, and in the use of mobile phone.

"So, if it's a mobile phone or something like that, it's open, I put it on the table, I put it on... who wants to use it, it's ok. So, it doesn't become my problem. One hundred percent like that." (Mr. A)

"We talked, I mean, a female friend wants to come here, there is a friend, but she's a girl who wants to come here. how? If my wife allows it, let's ask her to come. If not, you can't, that's it. My wife is like that too. If a high school friend or something, a man wants to come here, what's that? If I say no, then no. If you say yes, then yes. Suppose I say, "Just come." It's okay to come, come, but if you don't, then no." (Mr. A)

"For the last time, thank God, it has been good. Whatever it is, he always tells me. So do I, no matter how small the things, I tell him. So, he doesn't too suspicious of me like before. Then, in the past, I always held my mobile phone, now I don't." (Mrs. F) 


\section{Pramudito \& Minza || The Dynamics of Rebuilding Trust}

\section{Benevolence}

The aspect of benevolence was shown by all perpetrators by giving more attention and taking more responsibility than before the infidelity was disclosed. Attention to family was shown by the perpetrators through building intensive communication with victims even when they were not together, while responsibility was shown by being more responsive in fulfilling household needs. Those things were confirmed by all victims. Specifically, in couple 3, benevolence was shown by the perpetrator by showing her sacrifice for the victim by quitting her new job so that the only one motorcycle they had could be used by the victim to work daily.

"He holds big responsibility for his wife, children, family, love for family. I admit, I salute him because he is very responsible." (Mrs. B)

"And now I'm trying to build the goodness in household for my wife and children. I'm teaching, I'm teaching to my wife and children that if we do good, we sow good. There must be something called goodness, right like that, and we don't do anything bad." (Mr. C)

"The problem here is that I have only one motorbike left, only one left, my husband is confused about going out of town, while I also have to go to the office in the morning. That's the obstacle, then in the end, it's a bit hard, actually this has been given by God, but I don't want my husband to be the one who loses again. I said, "Okay, I'll give in." Maybe from here, so that the husband will trust me more. That's all." (Mrs. F)

\section{Religiosity}

After the infidelity disclosure, all perpetrators appeared to have an increased level of religiosity, that was showed in more diligent in prayers and deepened religious doctrine. Each perpetrator also joined spiritual community and actively involved in its activities together with the victims.
"I think that communication and worship are very important. So now, if there is not anything that really important, it's rare for my family to leave worship or leave prayer. That's it. So, it's rare if there is not anything really important. If there are church services together, we will arrange the time." (Mr. A)
"When we have a strong faith, we will be able to resist all the temptations the world offers. We must refuse because it is not pleasing God, such as the infidelity, and so on. That's what makes us fall deeper into sin, but when our faith, our lives is on the way of truth, the Lord Jesus who is the Lord and Savior of our lives, oh, we will not be shaken by such things." (Mr. C)
"And may God also grant it, and I am given the opportunity to grow and be closer to God, become a family, a healthy family, a family that doesn't have to be like yesterday." (Mrs. F)

\section{Discussion}

This research aimed to describe the dynamics of rebuilding trust and trustworthiness in marital relationship post infidelity disclosure. In comparison of the background of each participant, there were some similarities of the three couples. Victims in all three couples had older ages and higher education levels than perpetrators. This caused a tendency for victims to control the perpetrators. In this case, victims, especially in couple 2 and 3, appeared to control perpetrator's friendship, especially by frequently giving advice to the perpetrators to restrict their relationships with the opposite sex and to restrict their mobile phone usage. These efforts were different from victim in couple 1 who was only monitoring the perpetrator's activities via phone and checking perpetrator's mobile phone routinely. These efforts of control were done by victims to identify and prevent the risk of recurrence of infidelity in the future. Those were important because the initial possible causes of infidelity were the seduction from a third party and the lack of monitoring by the spouse as the risk factors that had to always be anticipated. Basically, relationship based on trust involved risk taking because there would always be a risk of loss in every relationship that needed trust (Evans \& Krueger, 2009; Hardin, 2002). Therefore, to minimize the risk of loss of the faithfulness of perpetrators, victims needed to control and monitor perpetrator's behaviors and social relationships to identify and prevent risk of infidelity recurrence in the future. 
As the effect of risk identification and prevention efforts by the victims, perpetrators especially in couple 2 and 3 appeared to show different responses. These differences appeared from the way perpetrator in couple 2 responding to victim's demand to break all his friendship in the past. Perpetrator in couple 2 first rejected that demand. However, after going through some contemplation, perpetrator in couple 2 then decided to fulfill the victim's demand. In contrast, the perpetrator in couple 3 willfully and without resistance decided to not be going back to work in the same field as before the infidelity disclosure. These two different responses showed that female perpetrator tended to be more obedient compared with male perpetrator.

On the other hand, previous research found that women showed lower tendency to lose trust were are more inclined to rebuild trust toward perpetrators compared to men, because women cared more about the integrity of relationship than men (Haselhuhn et al., 2015). This could be an explanation of why victims in couple 1 and 2 decided to stay in their marriage and why they still believe that the perpetrators were still trustworthy and would be faithful even after being unfaithful more than once (couple 1) or got involved in infidelity for a long time (couple 2). In couple 3, victim remained with the marriage and willing to accept perpetrator even though he still found it difficult to fully trust the perpetrator for several months post infidelity disclosure because he still often remembered the occurrence of the infidelity disclosure. This research result showed that both men and women cared about the integrity of marriage even though men personally appeared to have greater difficulty in rebuilding trust and still anticipating the possibility of infidelity recurrence. Other than because infidelity happened more than once in short interval of time, this could happen because men basically felt much more jealous and distressed after the infidelity disclosure so he overestimated the chance of future infidelity recurrence by their spouse (Brase et al., 2014; Edlund et al., 2006; Fisher et al., 2009; Goetz \& Causey, 2009; Schützwohl, 2007; Tagler \& Jeffers, 2013).

The dynamics of the three couples appeared to have similarities. All victims, regardless their gender, appeared to have similar predictability, of which in line with earlier research. Buchan et al. (2008) stated that men and women generally had comparable ability in predicting how much they can accept the outcomes of the trust they gave. In other words, the giver of the trust had to consider the possible outcomes that could be obtained and had to be able to predict whether the receiver of the trust could really be trusted (Evans et al., 2013). Predictability was firstly built from consistency of behavioral repetition and social environment stability (Rempel et al., 1985) and was supported by risk identification and prevention efforts described in the previous pages. In this case, behavioral repetition consistency and social environment stability in couple 2 appeared to be better than the other two couples because an absence of perpetrator's suspicious behaviors of infidelity recurrence, and the social environment was conditioned positively after the infidelity disclosure. This is in contrast to couple 1 where victim detected a possible behavior of the perpetrator that might lead to infidelity with prepetrator's ex-girlfriend although it could be prevented in the end. In the case of couple 3, the time span of personal and relational recovery was relatively short, so the consistency of behavioral repetition was not truly appeared. However, there was social environment stability in perpetrator in couple 3 because she did not go back to work again and spent more of her time in home. The social environment stability also developed when both the perpetrator and victim in all three couples joined the same spiritual community.

In the condition that the victims could not predict and there was not strong evidence of perpetrator's behavior, the victims needed a belief. Belief represented secure feeling that enabled individual to get assurance that other party would be responsible and cared about their goals even though there was possibility of uncertain changes in the future (Rempel et al., 1985). On this aspect, all victims had belief for the faithfulness of the perpetrators in the future even though it was gained through different ways. In couple 2, the victim had strong belief that the perpetrator would not be involved in infidelity anymore, so the victim found no difficulty to have belief that perpetrator will always be faithful in the future. In couple 1 and 3, although the victims did not yet find strong reasons to believe the perpetrator's faithfulness in the future, they still could belief that the perpetrator will be faithful in the condition that they always kept and watched over the perpetrators from the possibilities of infidelity recurrence. In other words, belief held victims in couple 1 and 3 was a conditional belief, and the condition to extablish this belief had to be fulfilled by the victims themselves, those were to do some efforts to identify and prevent the risk of infidelity recurrence. 
Specifically, in couple 3, although the infidelity occurred twice in a short time interval between two infidelity disclosures, the victim still stated his belief that the perpetrator will be faithful in the future. This was possible because men tend to be more trusting than women (Derks et al., 2014; Lemmers-Jansen et al., 2017; Schwieren \& Sutter, 2008). On the other hand, men tend to estimate that women will put more efforts in committing to something (Schwieren \& Sutter, 2008). This could be the answer why man as victim in couple 3 could start rebuilding his belief in early stages toward perpetrator's faithfulness despite the short time interval of recovery process post infidelity disclosure.

On the relational aspects, both victims and perpetrators needed to do some efforts together to recover their relationship. From the research data, two relational aspects in rebuilding trust were found as the aspects of intimacy and reciprocity. Intimacy of all couples appeared similar. The intimacy in each couple was attained by building more intensive communication, establishing closer relationship, and expressing more love. Intimacy built by all three couples could help the victims to evaluate the perpetrators and their relationships more positively. That was because the closeness of relationship could make the trust giver's appraisal to the trustee be different compared to without closeness (Faturochman \& Minza, 2014). The positive appraisal emerged by intimate relationship could establish secure feeling, either for victims or perpetrators, about their marital relationship. Therefore, intimacy could also support strengthened belief towards spouse's faithfulness through establishing secure feeling.

The aspect of reciprocity was found in couple 1 and 2, whereas couple 3 had not built this aspect yet because of the short time interval between the two infidelity disclosures at the times of this research, thus the victim might still feel difficult to fully trust the perpetrator. Reciprocity found in couple 1 and 2 appeared in the form of mutual understanding. Reciprocity also appeared when the victim had comparable level of trust with the level of trust that the perpetrators had toward the victims, at which point the reciprocity will appear in form of mutual understanding in aerly stages. In general, reciprocity showed the individual tendency to adjust their behavior toward their spouse's behavior (Thielmann \& Hilbig, 2015). In this case, perpetrators had to adjust their behavior by showing positive changes through being faithful, while the victims also had to be still trustworthy by showing their faithfulness, even after the past betrayal of their trust by perpetrator. Therefore, a reciprocal cooperation to build a good relationship and to understand the behavioral tendency of one another could be created. This reciprocal relationship could support the victim's trust rebuilding toward perpetrator and maintain the trust of perpetrator toward the victim. The reciprocity can eventually emerge in a mutual trust relationship. In other words, reciprocity started to emerge in the process of rebuilding trust of victim and fully established after the victim's trust was fully rebuilt. Onwards, reciprocity would sustainably strengthen the victim's trust toward the perpetrator, and strengthen the perpetrator's motivation to always show the trustworthiness from time to time.

The perpetrators of all couples appeared to show similarities in rebuilding trustworthiness in four aspects: commitment, openness and honesty, benevolence and religiosity. Commitment could strengthen the rebuilding of trustworthiness because it could be the first assurance post infidelity disclosure that reduced the possibility of infidelity recurrence in the future. By committing to the victim and proving the commitment through restricting relationship with opposite sex, it built the resistance within perpetrator to resist seduction of infidelity from time to time, so they could avoid the desires and chances to get involved in infidelity again.

On another note, the commitment aspect seemed to be different in gender. The perpetrator in couple 2 firstly refused the victim's demand to break all his friendships in the past even though finally he fulfilled it after his contemplation. Contrast with that, the perpetrator in couple 3 realized her role as a wife to be a companion and helper for her husband. Her awareness of the role of a wife then encouraged her to always be obedient toward the victim. The obedience toward the victim was shown by always asking for the approval from victim in all decision making and in everything work-related. Besides that, obedience was also shown by perpetrator by honoring the victim's instruction to stop working in the same field as before the infidelity disclosure and to restrict relationships with the opposite sex. Those instructions were obediently done by the perpetrator without rejection at all. In other words, female perpetrator tended to be more obedience compared to male perpetrator. Obedience in general was an act to follow instruction from the authority holder (Watson, 1984). Obedience shown by perpetrator, especially in couple 3, could support the risk identification and 
prevention efforts done by the victim, and victim's predictability toward the perpetrator.

After stating and proving the commitment, openness and honesty also became the important aspect in the rebuilding of trustworthiness of the perpetrators in all couples. This aspect was important because the couples in the process of rebuilding their relationship post infidelity disclosure needed more openness and honesty in their relationship (Olson et al., 2002). In this case, all perpetrators in couple 1, 2, and 3 had shown openness and honesty toward victims in their daily lives. This aspect specifically was shown by the frequent telling by perpetrators about their work activities and their relationship with others, as well as their mobile phone usage. These could be the evidence of no hidden relationship between perpetrators and third party, and also be the evidence of self-integrity of perpetrators. As confirmed, the victims in couple 2 and 3 never found any signs of suspicious communications in the perpetrator's mobile phone since the last infidelity disclosure, while the victim in couple 1 had found communications between perpetrator and his ex-girlfriend that led to infidelity since the last infidelity disclosure. In general, both of aspects of commitment as well as openness and honesty that shown by perpetrator could support the establishment of predictability aspect in trust rebuilding.

On the other hand, all perpetrators also tried to prove that they had changed to a better person by showing benevolence toward victims. According to Thielmann and Hilbig (2015), benevolence showed that each perpetrator had the willingness to change to be a better person than before the infidelity disclosure. Therefore, positive changes through benevolence in perpetrators were also the basis for each victim's trust rebuilding. Rempel et al. (1985) stated that evaluation toward facts and experiences in the relationship could support the trust building. So, the evaluation toward benevolence facts from perpetrators post infidelity disclosure was a reference for victims to trust the perpetrators again. Specifically, benevolence shown by perpetrators through greater attention (all couples), carrying bigger responsibilities (couple 1 and 2) and doing sacrifice for the victim (couple 3). In the case of perpetrator in couple 3, through her own awareness that the role of a wife was as a companion and helper for her husband and not as the main source of income, the perpetrator decided to quit her new job, so that the only motorcycle that they have could be used by the victim to do the daily activities. In general, this showed an act of altruism. Altruism could be understood as behavioral tendency to bring benefit for others by doing certain sacrifice (Kerr et al., 2004). In comparison, sacrifice reflecting the altruistic side in the perpetrator was not found in the couple 1 and 2. Therefore, it can be stated that women tend to be more altruistic than men. In line with the result of this research, previous research also found that women tend to be more altruistic than men (Branas-Garza et al., 2018).

All perpetrators also showed significant increase in religiosity. This was seen in the increase of diligence of each perpetrator to pray and follow the religious doctrines, as well as implementing them in their daily lives. Victim thought that the more diligent the perpetrator in praying and following the religious doctrines, the less the possibility of infidelity recurrence in the future. This was in line with the statement of Burdette et al. (2007) that the frequency of individual attendance in the house of prayer and the understanding of religious doctrines were related to the decreased chance of infidelity. By building a good religious life, perpetrators could rebuild their trustworthiness because increase in religious activity could be a guarantee for the victims to see the decrease of possibility of infidelity recurrence in the future. Meanwhile, increase in religiosity strengthened victim's belief that perpetrators would never be involved in infidelity anymore, because infidelity was contradictive with religious values that they implemented in daily lives. These religious values could protect the perpetrators from negative behaviors, including infidelity. Protected from negative behaviors, the perpetrators could prove that they could be trustworthy and faithful to the victims. Generally, both benevolence and religiosity supported the belief aspect in trust rebuilding because those aspects could also provide sense of security in victims.

\section{Conclusion}

Trust post infidelity disclosure could be rebuilt by five aspects. The three aspects were personally established by the victims: risk identification and prevention, predictability, and belief, while the two other aspects were relationally established by the couples: intimacy and reciprocity. This study 
also found four aspects to rebuild trustworthiness that was actively established by the perpetrators: commitment, openness and honesty, benevolence and religiosity.

Time interval between infidelity disclosure and data collection period in couple 3 may be a limitation of this research. These conditions showed that the rebuilding process of trust and trustworthiness on couple 3 was still on the early stages. Hence, couple 3 had not shown the fully dynamics of trust and trustworthiness yet, unlike the other two couples. This limitation was due to the limited availability of research participants. As also, this research topic was in sensitive area and was taboo in our society.

\section{Recommendation}

Future research should establish criteria for research participants, more specifically for the case of gender, counsellor involvement, and the duration post infidelity disclosure. Gender homogeneity on the side of the victims and the side of perpetrators might make the process of analysis easier. Next research could further consider uniformity in counsellor involvement because there were possibilities that personal and relational recovery processes will be different between couples with and without counsellor in handling conflicts post infidelity disclosure. Finally, duration post infidelity disclosure should be defined in early research design, because in short duration after infidelity disclosure, the recovery process might still be in the early stages and the dynamics of relationship recovery has not been fully established yet.

\section{Funding}

This research received no external funding.

\section{Authors'contribution}

First author contributed to literature review, design of the study, data collection, analysis, report of findings, and development of the manuscript. Second author, as supervisor, provided guidance and advice related to the research method and analysis process, and also overview about the concept of trust and trustworthiness.

\section{Conflict of interest}

The authors declare no conflict of interest regarding the contents of this manuscript.

\section{Orcid ID}

Anselmus Agung Pramudito 0000-0001-7911-4374

Wenty Marina Minza 0000-0002-3805-2717

\section{References}

Abrahamson, I., Hussain, R., Khan, A., \& Schofield, M. J. (2012). What helps couples rebuild their relationship after infidelity? J. Fam. Issues, 33(11), 1494-1519. https: / / doi . org / 10.1177 / $0192513 X 11424257$

Allen, E. S., \& Atkins, D. C. (2012). The association of divorce and extramarital sex in a representative U.S. sample. J. Fam. Issues, 33(11), 1477-1493. https:/ / doi.org/10.1177/0192513X12439692

Amato, P. R., \& Previti, D. (2003). People's reasons for divorcing: Gender, social class, the life course, and adjustment. J. Fam. Issues, 24(5), 602-626. https://doi.org/10.1177/0192513x03254507

Baucom, D. H., Snyder, D. K., \& Gordon, K. C. (2009). Helping couples get past the affair: A clinician's guide. New york, Guilford Press. 
Branas-Garza, P., Capraro, V., \& Rascon-Ramirez, E. (2018). Gender differences in altruism: Expectations, actual behaviour and accuracy of beliefs. Econ. Lett., 170, 19-23. http: / / arxiv. org/abs/1606.04900

Brase, G. L., Adair, L., \& Monk, K. (2014). Explaining sex differences in reactions to relationship infidelities: Comparisons of the roles of sex, gender, beliefs, attachment, and sociosexual orientation. Evol. Psychol., 12(1), 73-96. https:/ / doi.org/10.1177/147470491401200106

Buchan, N. R., Croson, R. T., \& Solnick, S. (2008). Trust and gender: An examination of behavior and beliefs in the Investment Game. J. Econ. Behav. Organ., 68(3-4), 466-476. https: / / doi.org /10. 1016/j.jebo.2007.10.006

Burdette, A. M., Ellison, C. G., Sherkat, D. E., \& Gore, K. A. (2007). Are there religious variations in marital infidelity? J. Fam. Issues, 28(12), 1553-1581. https : / / doi . org / 10 . 1177 / 0192513X07304269

Buskens, V. (2002). Social networks and trust. Dordrecht, Kluwer Academic Publishers.

Derks, J., Lee, N. C., \& Krabbendam, L. (2014). Adolescent trust and trustworthiness: Role of gender and social value orientation. J. Adolesc., 37(8), 1379-1386. https : / / doi . org / 10.1016 / j . adolescence.2014.09.014

Dickie, J. (2015). Trust and conflict resolution: Relationship building for learning. Procedia - Soc. Behav. Sci., 197, 2066-2073. https:/ / doi.org/10.1016/j.sbspro.2015.07.576

Edlund, J. E., Heider, J. D., Scherer, C. R., Farc, M.-M., \& Sagarin, B. J. (2006). Sex differences in jealousy in response to actual infidelity. Evol. Psychol., 4(1). https : / / doi . org / 10.1177 / 147470490600400137

Evans, A. M., Athenstaedt, U., \& Krueger, J. I. (2013). The development of trust and altruism during childhood. J. Econ. Psychol., 36, 82-95. https://doi.org/10.1016/j.joep.2013.02.010

Evans, A. M., \& Krueger, J. I. (2009). The psychology (and economic) of trust. Soc. Personal. Psychol. Compass, 3(6), 1003-1017. https:/ / doi.org/10.1037/0033-2909.85.3.441

Faturochman, \& Minza, W. M. (2014). Exploring Personal and Relational Trustworthiness. Jurnal Psikologi.

Fisher, M., Geher, G., Cox, A., Tran, U. S., Hoben, A., Arrabaca, A., Chaize, C., Dietrich, R., \& Voracek, M. (2009). Impact of relational proximity on distress from infidelity. Evol. Psychol., 7(4), 560-580. https:/ / doi.org/10.1177/147470490900700406

Fisher, M., Voracek, M., Rekkas, P. V., \& Cox, A. (2008). Sex differences in feelings of guilt arising from infidelity. Evol. Psychol., 6(3), 436-446. https://doi.org/10.1016/B978-0-12-375000-6.00160-9

Füzér, K. (2016). The social theory of trust and the sociological theory of social capital. Belvedere Meridionale, 28(1), 132-139. https:/ / doi.org/10.14232/belv.2016.1.9

Goetz, A. T., \& Causey, K. (2009). Sex differences in perceptions of infidelity: Men often assume the worst. Evol. Psychol., 7(2), 253-263. https:/ / doi.org/10.1177/147470490900700208

Goldie, M. M. (2013). Infidelity and forgiveness : Therapists' views on reconciliation and restoration of trust following disclosure of infidelity. All Theses Diss., 3834.

Hardin, R. (2002). Trust and trustworthiness. New York, Russell Sage Foundation. https: / / doi.org /10. 1002/9781119138341.ch14

Haselhuhn, M. P., Kennedy, J. A., Kray, L. J., Van Zant, A. B., \& Schweitzer, M. E. (2015). Gender differences in trust dynamics: Women trust more than men following a trust violation. J. Exp. Soc. Psychol., 56, 104-109. https:/ / doi.org/10.1016/j.jesp.2014.09.007

Kerr, B., Godfrey-Smith, P., \& Feldman, M. W. (2004). What is altruism? Trends Ecol. Evol., 19(3), $135-140$. https://doi.org/10.1016/j.tree.2003.10.004

Kuroki, M. (2013). Opposite-sex coworkers and marital infidelity. Economics Letters, 118(1), 71-73. https: / / doi.org/10.1016/j.econlet.2012.09.023

Lemmers-Jansen, I. L., Krabbendam, L., Veltman, D. J., \& Fett, A. K. J. (2017). Boys vs. girls: Gender differences in the neural development of trust and reciprocity depend on social context. Dev. Cogn. Neurosci., 25, 235-245. https: / /doi.org/10.1016/j.dcn.2017.02.001

Lishner, D. A., Nguyen, S., Stocks, E. L., \& Zillmer, E. J. (2008). Are sexual and emotional infidelity equally upsetting to men and women? Making sense of forced-choice responses. Evol. Psychol., 6(4), 147470490800600. https://doi.org/10.1177/147470490800600412 
Luhmann, N. (2000). Familiarity, confidence, trust: Problems and alternatives. In D. Gambetta (Ed.), Trust mak. break. coop. relations (electronic, pp. 94-107). Department of Sociology, University of Oxford. https://doi.org/10.1017/CBO9781107415324.004

Marin, R. A., Christensen, A., \& Atkins, D. C. (2014). Infidelity and behavioral couple therapy: Relationship outcomes over 5 years following therapy. Couple Fam. Psychol. Res. Pract., 3(1), 1-12. https:/ / doi.org/10.1037/cfp0000012

Mayer, R. C., Davis, J. H., \& Schoorman, F. D. (1995). An integrative model of organizational trust. Acad. Manag. Rev., 20(3), 709-734.

Miller, S. L., \& Maner, J. K. (2008). Coping with romantic betrayal: Sex differences in responses to partner infidelity. Evol. Psychol., 6(3), 147470490800600. https : / / doi . org / 10.1177 / 147470490800600305

Olson, M. M., Russell, C. S., Higgins-Kessler, M., \& Miller, R. B. (2002). Emotional processes following disclosure of an extramarital affair. J. Marital Fam. Ther., 28(4), 423-434. https: / / doi.org/10. 1111/j.1752-0606.2002.tb00367.x

Peluso, P. R. (2007). Infidelity: A practitioner's guide to working with couples in crisis. New York, Routledge.

Pitakasari, A. R. (2012). Kasus nikah siri dan perselingkuhan di Yogyakarta tinggi [The case of unregistered marriage and infidelity in Yogyakarta is high]. http: / / www.republika.co.id / berita / nasional / jawa-tengah-diynasional / 12 / 12 / 10 / met2ik-wcc-kasus-nikah-siri-danperselingkuhan-diyogyakarta-tinggi

Prasetyo, S. E. (2017). Sehari 16 pasutri minta cerai, selingkuh bukan penyebab utama [Sixteen married couples register for divorce in a day, infidelity is not the main reason]. https://www.jawapos. $\mathrm{com} / \mathrm{read} / 2017 / 05 / 24 / 132336$ / sehari-16-pasutriminta-cerai-selingkuh-bukan-penyebabutama

Purnama, R. R. (2017). Perceraian karena sosmed merupakan bentuk lain perselingkuhan fisik [Divorce because of social media is another form of physical infidelity]. https://metro.sindonews.com/ $\mathrm{read} / 1245315 / 170 /$ perceraian-karenasosmed-merupakan-bentuk-lain-perselingkuhan-fisik1507102613

Rempel, J. K., Holmes, J. G., \& Zanna, M. P. (1985). Trust in close relationships. J. Pers. Soc. Psychol., 49(1), 95-112. https://doi.org/10.1037/0022-3514.49.1.95

Rousseau, D. M., Sitkin, S. I. M. B., Burt, R. S., \& Colin, C. (1998). Not so different after all: A cross-discipline view of trust. Acad. Manag. Rev., 23(4), 652. https://doi.org/10.2307/259051

Schützwohl, A. (2007). Decision strategies in continuous ratings of jealousy feelings elicited by sexual and emotional infidelity. Evol. Psychol., 5(4), 147470490700500. https: / / doi.org / 10.1177 / 147470490700500410

Schwieren, C., \& Sutter, M. (2008). Trust in cooperation or ability? An experimental study on gender differences. Econ. Lett., 99(3), 494-497. https://doi.org/10.1016/j.econlet.2007.09.033

Shackelford, T. K., Besser, A., \& Goetz, A. T. (2007). Personality, marital satisfaction, and probability of marital infidelity. Individ. Differ. Res., 6(1), 1-18.

Simpson, J. A. (2007). Psychological foundations of trust. Curr. Dir. Psychol. Sci., 16(5), 264-268. https: //doi.org/10.1111/j.1467-8721.2007.00517.x

Smith, J. A. (2009). Dasar-dasar psikologi kualitatif: Pedoman praktis metode penelitian [Fundamentals of qualitative psychology: Practical guidance of research method]. Bandung, Nusa Media.

Snyder, D. K., Baucom, D. H., \& Gordon, K. C. (2008). An integrative approach to treating infidelity. Fam. J., 16(4), 300-307. https://doi.org/10.1177/1066480708323200

Tagler, M. J., \& Jeffers, H. M. (2013). Sex differences in attitudes toward partner infidelity. Evol. Psychol., 11(4), 821-832. https://doi.org/10.1177/147470491301100407

Takariawan, C. (2015). Di Indonesia 40 perceraian setiap jam [In Indonesia 40 divorces every hour]. https : / / www . kompasiana . com / pakcah / diindonesia - 40 - perceraian - setiap jam54f357c07455137a2b6c7115

Thielmann, I., \& Hilbig, B. E. (2015). The traits one can trust: Dissecting reciprocity and kindness as determinants of trustworthy behavior. Personal. Soc. Psychol. Bull., 41(11), 1523-1536. https: // doi.org/10.1177/0146167215600530

van Hooff, J. (2017). An everyday affair: Deciphering the sociological significance of women's attitudes towards infidelity. Sociol. Rev., 65(4), 850-864. https://doi.org/10.1111/1467-954X.12417 
Pramudito \& Minza || The Dynamics of Rebuilding Trust

Wardhati, L. T., \& Faturochman. (2006). Psikologi pemaafan [The psychology of forgiveness]. Buletin Psikologi, 1-11.

Watson, D. L. (1984). Social psychology, science and application. Illinois, Scott, Foresman; Company.

Young, K. P., Y.Y. Tai, L., Chau, B. C., Yim, V. P., Kei, L. C., \& Cheung, W. Y. (1995). Study on marriages affected by extramarital affairs. Hong Kong, Caritas Family Service; the Department of Social Work \& Social Administration University of Hong Kong.

Zare, B. (2011). Review of studies on infidelity. 3rd Int. Conf. Adv. Manag. Sci. IPEDR, 19, 182-186. 